\title{
Measurement of Enzyme Activity in Single Cells by Voltammetry Using a Microcell with a Positionable Dual-Electrode
}

Ning Gao, Minghui Zhao, Xiaoli Zhang, and Wenrui Jin*

School of Chemistry and Chemical Engineering, Shandong University, Jinan 250100, China

*Corresponding author. (e-mail) jwr@sdu.edu.cn; (Fax)+86-531-8856-5167.

\section{Supporting Information}

\section{RESULTS AND DISCUSSION}

Table 1 Mean PO Activity Concentration, Cell Concentration and Mean PO Activity in a Single Neutrophil for Ten Neutrophil Extracts

\begin{tabular}{cccc}
\hline $\begin{array}{c}\text { Neutrophil } \\
\text { extract }\end{array}$ & $\begin{array}{c}\text { Mean activity } \\
\text { concentration of PO } \\
\left(10^{-4} \mathrm{U} / \mathrm{mL}\right)\end{array}$ & $\begin{array}{c}\text { Cell concentration } \\
\left(10^{4} \text { cells } / \mathrm{mL}\right)\end{array}$ & $\begin{array}{c}\text { Mean PO activity in a } \\
\text { single neutrophil } \\
\left(10^{-8} \mathrm{U}\right)\end{array}$ \\
\hline 1 & 2.12 & 1.3 & 1.7 \\
2 & 9.45 & 4.5 & 2.1 \\
3 & 4.83 & 3.9 & 1.2 \\
4 & 6.10 & 7.0 & 0.87 \\
5 & 5.01 & 3.3 & 1.5 \\
6 & 3.63 & 2.8 & 1.3 \\
7 & 2.13 & 2.2 & 0.97 \\
8 & 1.80 & 2.3 & 0.78 \\
9 & 5.93 & 4.3 & 1.4 \\
10 & 5.36 & 6.0 & 0.89 \\
\hline
\end{tabular}


Table 2 Mean PO Activity Concentration, Cell Concentration and Mean PO Activity in a Single APL Cell for Ten APL cell Extracts

\begin{tabular}{cccc}
\hline $\begin{array}{c}\text { APL cell } \\
\text { extract }\end{array}$ & $\begin{array}{c}\text { Mean activity } \\
\text { concentration of PO } \\
\left(10^{-3} \mathrm{U} / \mathrm{mL}\right)\end{array}$ & $\begin{array}{c}\text { Cell concentration } \\
\left(10^{4} \text { cells } / \mathrm{mL}\right)\end{array}$ & $\begin{array}{c}\text { Mean PO activity in a } \\
\text { single APL cell } \\
\left(10^{-7} \mathrm{U}\right)\end{array}$ \\
\hline 1 & 2.23 & 0.76 & 2.9 \\
2 & 1.78 & 0.97 & 1.8 \\
3 & 2.39 & 0.95 & 2.5 \\
4 & 1.98 & 1.3 & 1.5 \\
5 & 2.07 & 0.86 & 2.4 \\
6 & 1.87 & 1.2 & 1.6 \\
7 & 1.86 & 0.72 & 2.6 \\
8 & 1.58 & 0.83 & 1.9 \\
9 & 2.21 & 0.99 & 2.2 \\
10 & 2.45 & 0.79 & 3.1 \\
\hline
\end{tabular}

Table 3 PO Activity, $A_{P O}$, in 18 SingleNeutrophils

\begin{tabular}{ccccccccccc}
\hline Neutrophil & 1 & 2 & 3 & 4 & 5 & 6 & 7 & 8 & 9 & 10 \\
\hline$A_{\mathrm{PO}}\left(10^{-8} \mathrm{U}\right)$ & 1.1 & 0.97 & 0.77 & 1.7 & 1.5 & 0.75 & 1.3 & 1.9 & 1.1 & 1.0 \\
Neutrophil & 11 & 12 & 13 & 14 & 15 & 16 & 17 & 18 & & \\
$A_{\mathrm{PO}}\left(10^{-8} \mathrm{U}\right)$ & 1.2 & 0.98 & 0.80 & 1.5 & 1.4 & 0.88 & 2.1 & 0.65 & & \\
\hline
\end{tabular}

Table 4 PO Activity, $A_{P O}$, in 14 Single APL Cells

\begin{tabular}{ccccccccccc}
\hline APL cell & 1 & 2 & 3 & 4 & 5 & 6 & 7 & 8 & 9 & 10 \\
\hline$A_{\mathrm{PO}}\left(10^{-7} \mathrm{U}\right)$ & 1.4 & 2.1 & 2.8 & 2.2 & 2.1 & 1.7 & 2.9 & 1.8 & 2.6 & 2.5 \\
APL cell & 11 & 12 & 13 & 14 & & & & & & \\
$A_{\mathrm{PO}}\left(10^{-7} \mathrm{U}\right)$ & 0.93 & 1.9 & 3.1 & 2.0 & & & & & & \\
\hline
\end{tabular}

